\title{
Alteration in ascorbate and ascorbate peroxidase in programmed cell death and oxidative stress
}

\author{
Annalisa Paradiso ${ }^{1}$, Franca Tommasi ${ }^{1}$, Laura De Gara ${ }^{1,2}$ and \\ Maria Concetta de Pinto*1
}

\author{
Address: ${ }^{1}$ Dipartimento di Biologia e Patologia Vegetale, Via Orabona 4, I-70125 Bari, Italy and ${ }^{2}$ Centro Interdipartimentale di Ricerche \\ Biomediche (CIR) Università Campus Biomedico, Via Longoni 83, I-00155 Roma, Italy \\ Email: Maria Concetta de Pinto* - depinto@botanica.uniba.it \\ * Corresponding author
}

from Cell Biology of Nitric Oxide and Cell Death in Plants

Yalta, Ukraine, 8-II September 2004

Published: 3I May 2005

BMC Plant Biology 2005, 5(Supp| I):S28 doi:I0.1 I86/I 47|-2229-5-SI-S28

Different stress conditions, of biotic and abiotic nature, enhance the cellular production of reactive oxygen species (ROS) [1]. Due to their reactive nature, ROS are potentially harmful to all cellular components. Apart their destructive nature, ROS behave as metabolic regulators, being considered as secondary messengers. Indeed, ROS can trigger pathways aimed at saving cells from demise; however, under certain conditions, they can also impair the cellular red/ox balance as to activate a programmed cell death (PCD) process $[2,3]$. These differences in the ROS-dependent responses seem to be due to different localization, timing and level of ROS production under different stimuli $[4,5]$. Moreover, the possibility that the co-production of other reactive species is a critical point for the activation of different defence responses has been recently underlined. Increasing attention has been paid to nitric oxide (NO) as a signal molecule synergically acting with ROS in the activation of PCD [6,7]. The level of ROS and the cellular redox homeostasis are regulated by different antioxidant systems; among these, ascorbate (ASC) plays a pivotal role, it being both a direct scavenger of ROS and the electron donor of ascorbate peroxidase (APX), a key enzyme for scavenging hydrogen peroxide in plant cells $[8,9]$.

Here we report data showing that in tobacco cultured cells a moderate oxidative stress did not lead to apoptotic or necrotic events whereas, when $\mathrm{H}_{2} \mathrm{O}_{2}$ production was increased over a certain range of concentration, an induction of cell death with the features of necrosis was achieved. On the other hand, when the tobacco cells were simultaneous treated with $\mathrm{NO}$ and $\mathrm{H}_{2} \mathrm{O}_{2}$ generators a
PCD program was triggered. The scavengers ASC and APX change differently under the various stress conditions. During the moderate oxidative stress a transient increase in APX activity occurred whereas, in the induction of cell necrosis, the activity of APX decreased proportionally to cell death. Under such conditions, no alteration in the APX gene expression was evident and 24 hours after the generation of the oxidative stress, APX activity was significantly increased in the surviving cells, in order to overcome the oxidative stress and to avoid further cell death. When the PCD program was triggered in these cells by the contemporary increase of $\mathrm{NO}$ and $\mathrm{H}_{2} \mathrm{O}_{2}$ the suppression of APX occurred both at the translation or post-translation level. The decrease in APX seems to be one of the first alteration in the redox regulating systems induced in the plant cells in route to PCD.

\section{References}

I. Dat J, Vandenabeele S, Vranovà E, Van Montagu M, Inzè D, Van Breusegem F: Dual action of the active oxygen species during plant stress responses. Cell Mol Life Sci 2000, 57:779-795.

2. Lam E, Kato N, Lawton M: Programmed cell death, mitochondria and the plant hypersensitive response. Nature 200I, 4II:848-853.

3. Vacca RA, de Pinto MC, Valenti D, Passarella S, Marra E, De Gara L: Production of reactive oxygen species, alteration of cytosolic ascorbate peroxidase and impairment of mitochondria metabolism are early events in heat shock-induced programmed cell death in tobacco bright-Yellow 2 cells. Plant Physiol 2004, 134: I 100-1 I 12.

4. Mittler R: Oxidative stress, antioxidants and stress tolerance. Trends Plant Sci 2002, 7:405-4I0.

5. De Gara L, de Pinto MC, Tommasi F: The antioxidant systems vis à vis reactive oxygen species during plant-pathogen interaction. Plant Physiol Biochem 2003, 41:863-870.

6. Delledonne M, Xia Y, Dixon RA, Lamb C: Nitric oxide functions as a signal in plant disease resistance. Nature 1998, 394:585-588. 
7. de Pinto MC, Tommasi F, De Gara L: Changes in the antioxidant systems as part of the signaling pathway responsible for the programmed cell death activated by nitric oxide and reactive oxygen species in tobacco Bright-Yellow 2 cells. Plant Physiol 2002, 130:698-708.

8. Smirnoff $\mathrm{N}$ : Ascorbic acid: metabolism and functions of a multi-facetted molecule. Curr Opin Plant Biol 2000, 3:229-235.

9. Noctor G, Foyer $\mathrm{CH}$ : Ascorbate and glutathione: keeping active oxygen under control. Annu Rev Plant Physiol Plant Mol Biol 1998, 49:249-279.

Publish with Bio Med Central and every scientist can read your work free of charge

"BioMed Central will be the most significant development for disseminating the results of biomedical research in our lifetime. " Sir Paul Nurse, Cancer Research UK

Your research papers will be:

- available free of charge to the entire biomedical community

- peer reviewed and published immediately upon acceptance

- cited in PubMed and archived on PubMed Central

- yours - you keep the copyright

Submit your manuscript here:

http://www.biomedcentral.com/info/publishing_adv.asp 